\title{
Effects of Concurrent Training and Intermittent Fasting on Structural, Functional, and Morphological Parameters of the Heart
}

\author{
Efectos del Entrenamiento Concurrente y el Ayuno Intermitente sobre los \\ Parámetros Estructurales, Funcionales y Morfológicos del Corazón
}

\begin{abstract}
Henrique Izaias Marcelo ${ }^{1}$; Paulo Henrique Aleixo ${ }^{2,3}$; Rafael Pereira da Silva ${ }^{2}$; Francis Lopes Pacagnelli ${ }^{1}$; Rejane Batista Brinholi Victorino da Silva ${ }^{1}$; José Carlos Silva Camargo Filho ${ }^{2}$, Everton Alex Carvalho Zanuto ${ }^{1} \&$ Robson Chacon Castoldi $^{1,2}$
\end{abstract}

MARCELO, H. I.; ALEIXO, P. H.; DA SILVA, R. P.; PACAGNELLI, F. L.; DA SILVA, R. B. B. V.; CAMARGO FILHO, J. C. S.; ZANUTO, E. A. C. \& CASTOLDI, R. C. Effects of concurrent training and intermittent fasting on structural, functional, and morphological parameters of the heart. Int. J. Morphol., 39(4):1190-1199, 2021.

SUMMARY: Intermittent fasting and concurrent training have been performed frequently to decrease body mass. The aim was to analyze the effects of concurrent training (CT) and intermittent fasting (IF) on cardiac remodeling. In total, 39 adult male Wistar rats were used, divided into four groups: control $(\mathrm{C}[\mathrm{n}=12])$, fasting control $(\mathrm{FC}[\mathrm{n}=11])$, training $(\mathrm{T}[\mathrm{n}=8])$ and fasting training $(\mathrm{FT}[\mathrm{n}=$ 8]).The CT protocol was composed of 12 sessions, with 30 minutes of aerobic training (AT) in the liquid medium at an intensity of $80 \%$ of the anaerobic threshold, followed by resistance training (RT) with 4 series of 10 aquatic jumps at an corresponding to $50 \%$ of body weight. The IF period was established at 12/12 hours, starting at 9 p.m. and ending at 9 a.m. Echocardiographic analyzes were performed before and after the intervention and, at the end of the experiment, samples of the cardiac tissue were collected to perform the histological analyses. Data analysis was performed using the Shapiro-Wilk tests, Analysis of Variance - ANOVA with Tukey's post-test, and KruskalWallis with Dunn's post-test. All procedures assumed an error of $5 \%(\mathrm{p}<0.05)$. Neither group showed alterations in the functional (min. $p=0.12-\max . p=0.83$ ) and structural parameters of the heart (min. $p=0.31-\max . p=0.83)$. A decrease was observed in the area of cardiomyocytes in the $\mathrm{T}(\mathrm{p}=0.001)$ and FT groups $(\mathrm{p}=0.001)$. The $\mathrm{CT}$ and IF did not alter the functional and structural parameters of the heart, but did cause a decrease in the area of the cardiomyocytes.

KEY WORDS: Histology; Cardiology; Heart; Rats; Exercise.

\section{INTRODUCTION}

The practice of physical training has been shown to be cardioprotective, preventing and limiting damage from several diseases, including cardiovascular diseases (Negrão, 2010; Pearson et al., 2017). Fasting has been used as a method to increase lipid oxidation during training programs and for promoting alterations in body composition (Marquezi \& Dos Santos Costa, 2008).

However, during a training session, if the intake/ expenditure ratio is negative (expenditure greater than the intake), it is likely that the individual will experience bodily alterations, such as loss of lean mass, suppression of the immune system, and even metabolic and hormonal alterations, due to the fact that the amount of nutrients present in the body is insufficient for energy demand (Fontan \& Amadio, 2015).
After intense training, the muscles need to recover, as during this period, the process of muscle glycogen replacement takes place, which will later be converted into glucose that can be used as an energy substrate. However, the lack of glucose during training can cause serious damage to the individual, such as hypoglycemia (Kleiner, 2009).

In this sense, physical performance can be altered by different aspects, such as: time of intake of liquid or solid food, intensity and type of physical training performed, among other factors (Biesek \& Alves, 2010). Therefore, the wrong diet can impair the physical and mental disposition of athletes during training programs. In this case, in order to avoid damage to health, homogeneity between calorie intake and training load is necessary (Ministério da Saúde, 2016).

\footnotetext{
${ }^{1}$ Universidade do Oeste Paulista, Faculty of Health Sciences, Department of Physical Education, Presidente Prudente, SP, Brazil.

${ }^{2}$ Universidade Estadual Paulista, Faculty of Science and Technology FTC / UNESP, Department of Physiotherapy, Presidente Prudente, SP, Brazil.

${ }^{3}$ State University of Campinas - UNICAMP, Faculty of Medical Sciences, Department of Orthopedics and Traumatology, Brazil.
} 
The practice of fasting, in line with physical training, contributes to reducing the stocks of energetic substrates that are used to form ATP, such as, for example, glucose. In the absence of this, the individual's body is in a state of hypoglycemia, since it has an important role in energy reactions during physical exercise (Mccardle et al., 2017).

According to the literature, it is known that concurrent training can promote cardioprotection to the heart (Welton et al., 2020). However, when the heart suffers some type of injury and cardiac cells undergo apoptosis, there is action from the Resident Cardiac Stem Cells (CTCR), which have the ability to differentiate into cardiomyocytes, promoting replacement of the lost cells (Beltrami et al., 2003; Mayfield et al., 2014). In addition, in cases of cardiac injury, vascular endothelial growth factor (VEGF) is released, which is responsible for increasing the amount of blood vessels, thus promoting greater blood supply to the heart (Henry et al., 2003; Atluri \& Woo, 2008; Testa et al., 2008; Taimeh et al., 2013). Therefore, little information is available about when concurrent training is added to intermittent fasting, so the present study becomes relevant when investigating the results of these methods on structural and functional parameters of the heart.

Therefore, the aim of the present study was to analyze the effects of concurrent training combined with intermittent fasting on structural, functional, and morphological parameters of the heart of Wistar rats.

\section{MATERIAL AND METHOD}

Ethical Procedures: The study was developed in compliance with the rules and ethical principles of the Brazilian College of Animal Experimentation (COBEA) and was approved by the Ethics Committee for the Use of Animals (CEUA-5372).

Division of groups and concurrent training protocol: In total, 39 male Wistar rats (Rattus novergicus albinus) were used, male, with a mean age of 150 days and weight of 431 \pm 2.94 grams. The animals remained in groups of 2 animals per box (polyethylene), with a controlled ambient temperature $\left(22 \pm 2{ }^{\circ} \mathrm{C}\right)$ and brightness (light/dark cycle of 12 hours).

The animals were divided into four groups: $\operatorname{control}(\mathrm{C}[\mathrm{n}$ =12]), fasting control (FC $[\mathrm{n}=11])$, training $(\mathrm{T}[\mathrm{n}=8])$, and fasting training (FT $[\mathrm{n}=8]$ ). Prior to beginning the training protocols, the rats were submitted to a period of adaptation to the liquid environment and equipment (10 -
$20 \mathrm{~min} /$ day, three days a week, for one week, with progressively increasing overload and duration). The adaptation period reduces the stress produced by the liquid medium and by the physiological alterations resulting from physical training (Manchado et al., 2006).

C Group: The animals remained loose in their cages, with free access to water and feed (feed for laboratory rats).

FC Group: The animals remained loose in their cages, with free access to water, however the feeding was controlled to a fasting period of 12 hours for 12 hours of free access to feed (Ferreira da Silva et al., 2011).

T Group: This training model was composed of two different exercise sessions, which require different energy sources during execution, one being predominantly aerobic (swimming) and the other with anaerobic predominance (jumping).

The aerobic training protocol was performed first, followed by the resistance training protocol. The protocols were formed sequentially, with a pause only to change the training area.

The aerobic training protocol consisted of three weekly sessions on non-consecutive days, comprising 30 minutes of swimming exercise, with an intensity of $80 \%$ of the anaerobic threshold (LAN), stipulated from the critical load test (Manchado et al.). For the swimming exercise, a tank was used, containing cylindrical polyvinyl chloride (PVC) tubes, $25 \mathrm{~cm}$ in diameter and $100 \mathrm{~cm}$ in height, with water at a depth of $70 \mathrm{~cm}$ (Ozaki et al., 2015).

For the resistance training protocol, four series of 10 jumps were used, with overload corresponding to $50 \%$ of the body weight of each animal. A polyvinyl chloride (PVC) tube, $25 \mathrm{~cm}$ in diameter, $80 \mathrm{~cm}$ in height, and $38 \mathrm{~cm}$ deep was used (Fig. 1). The overload was carried in a waistcoat made from elastic with a Velcro closure, attached to the chest area, specially made for this type of exercise (Ozaki et al., 2015). Access to water and feed was ad libitum for this group.

FT Group: This group was identical to the $\mathrm{T}$ group except that the animals were fasting, under the same model that was applied to the FC group (12x12 hours).

Intermittent fasting protocol: Intermittent fasting was performed with a $12 / 12$ protocol, that is, the animals performed 12 (twelve) hours of fasting for 12 (twelve) hours of feeding on every day of the week (Ferreira da Silva $e t$ $a l$.). The fasting period started at 9 p.m. and ended the next day at 9 a.m. The training took place 1 (one) hour before the 

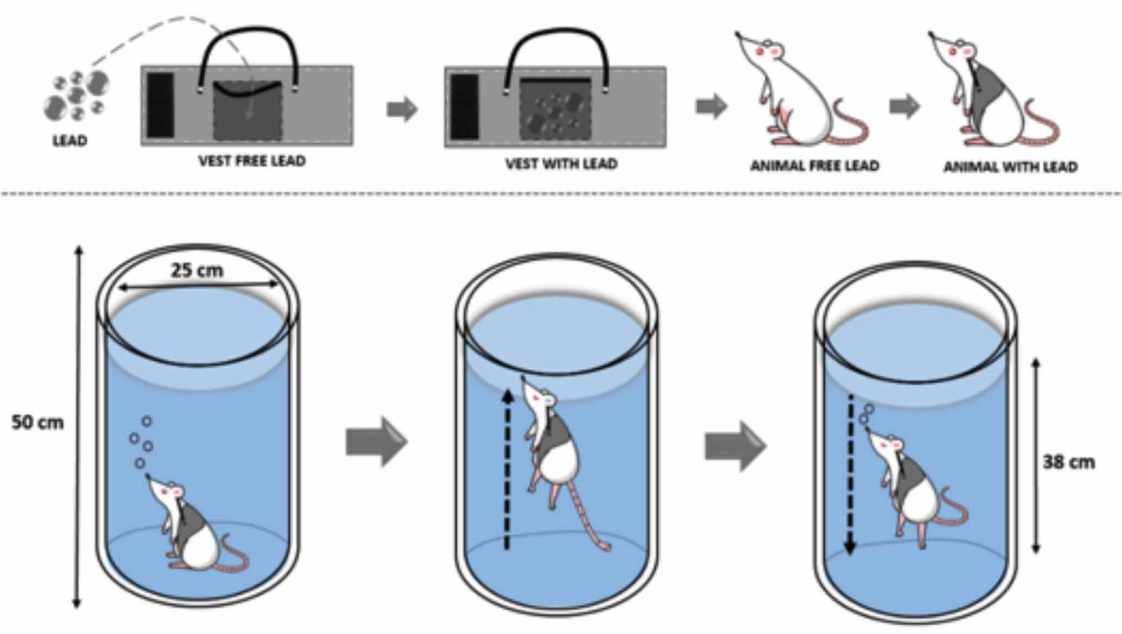

Fig. 1. Apparatus for fixing the load and diagram of the tube used for the maximum load test and water jump training. Source: The author, 2021.

beginning of the feeding period, so the animals performed the concurrent training while still fasting. Water consumption was ad libitum 24 (twenty four) hours a day for all animals.

Critical Load Test: The performance of the critical workload (CWL) and anaerobic capacity (CTA) was obtained by inducing exercise in three different stimuli. Three loads were selected for each animal, corresponding to 7,9 , and $11 \%$ of body weight, so that the animals would perform all efforts (Hill, 1993; Marangon et al., 2002).

The animals performed the exercise in order to enter exhaustion after between 2 and 10 minutes.21 In this way, we recorded the time limit (Tlim) to perform the exercise at each of the loads. The animals rested for 24 hours after each stimulus (Marangon et al.; Chimin et al., 2009; Castoldi et al., 2013). The values established for the two variables were obtained using the formula: Critical Load $=\mathrm{CWL}+(\mathrm{CTAx} 1 /$ Tlim).

After performing this procedure, it was possible to determine the aerobic capacity of each animal. This procedure was necessary to identify the intensity of effort in the swimming exercise.

Echocardiographic study: The echocardiographic evaluation was performed ( 24 hours after the final session) using a commercially available echocardiogram (General Electric Medical Systems, Vivid T8 Pro, Israel), equipped with a 5 to $12 \mathrm{MHz}$ multifrequency probe.

The rats were anesthetized by intramuscular injection of a mixture of ketamine (50 mg kg-1, IP Dopalen $®$ ) and xylazine (0.5 mg kg-1, IP, Anasedan®) (Minicucci et al.,
2010). A parasternal two-dimensional short-axis view of the left ventricle (LV) was obtained at the level of the papillary muscles. Mmode tracings were obtained from LV short axis views or below the tip of the mitral valve leaflets and at the level of the aortic valve and the left atrium. The mode $\mathrm{M}$ images of the LV were printed in black on a thermal printer (Sony UP-890MD), at a scanning speed of $100 \mathrm{~mm} / \mathrm{s}$. All LV structures were measured manually by the same observer. The measurements were calculated from the mean of at least five cardiac cycles in the Mmode tracings. Echocardiography consisted of evaluating the parameters of the striated cardiac muscle detailed below. All measures were carried out in accordance with the recommendations of the American Society of Echocardiography/ European Association of Echocardiography (Lang et al., 2005).

Structural parameters: Left atrioventricular valve (Valva bicuspidal, Mitral Valve) Area (MVA $\left[\mathrm{cm}^{2}\right]$ ); Left ventricular internal diameter in systole (LVIDs [mm]); Left Ventricular Mass in diastole (LVMd [g]); Left Ventricular Mass in systole (LVMs [g]); Left Ventricular Mass in diastole according to the American Society Echocardiogram formula (LVMd [ASE] [g]); Left Ventricular Mass in systole according to the American Society Echocardiogram formula (LVMs [ASE] [g]); Left ventricular posterior wall in diastole (LVPWd [mm]); Left ventricular posterior wall in systole (LVPWs [mm]); Relationship between left atrium and aorta (LA/Ao); Interventricular septum in diastole (IVSd [mm]); Interventricular septum in systole (IVSs [mm]); Diameter of the Aorta (D Ao [mm]); Diameter of the Left Atrium (D $\mathrm{LA}[\mathrm{mm}])$.

Functional parameters: Heart rate in beats per minute (HR [bpm); Relationship between E wave and A wave of the mitral valve (E/A MV); Ejection Fraction (EF [teich] [\%]); Isovolumetric Contraction Time (IVCT [ms]); Isovolumetric Relaxation Time (IVRT [ms]); Mitral Valve Half Period Pressure (PHT MV [ms]); Ejection time (Time [ms]); Peak E Wave Velocity of mitral valve flow (V.A MV [cm/s]); (atrial contraction) Peak E Wave Velocity of mitral valve flow (rapid ventricular filling indicator) (V.E MV $[\mathrm{cm} / \mathrm{s}]$ ); and Rate of change of pressure over time in the Right atrioventricular valve (mitral valve) ( $\mathrm{LV}$ function indicator) ( $\mathrm{MV} \mathrm{dp} / \mathrm{dt}$ $[\mathrm{mmHg} / \mathrm{s}])$. 
Feed consumption: Feed consumption was noted at each change of feed and water and the parameters of each group were analyzed. This variable was established by the ratio between the animal's body mass (Panimal) and feed consumption, both in grams (g). The consumption was calculated by the content of the feed offered (FO) and subtracted from the leftover (LO). Thus, the formula was established [Panimal/FO-LO] (Dudley \& Fleck, 1987).

Sample collection and preparation: Forty-eight hours after the final training session, the animals were euthanized by anesthetic overdose: ketamine hydrochloride and xylazine hydrochloride, injected intraperitoneally (Castoldi et al.). After euthanasia, the heart of each animal was removed by a surgical procedure, and then stored in a formaldehyde solution (10 $\%$ ) for histological processing (Gimenes et al., 2015).

Histological Processing of the Cardiac Muscle: Samples of the left ventricle were fixed in a $10 \%$ buffered formaldehyde solution for a period of 48 hours, after which the tissue was embedded in paraffin blocks, for later preparation of the histological slides.

After fixation, the hearts were sectioned transversely immediately below the coronary sulcus, and longitudinally, so that we could obtain only the left ventricles. Next, the hearts were washed, dehydrated, and embedded in paraffin (Noh et al., 2015). The blocks containing the fragments of the cardiac tissue were cut in a rotating microtome by the semi-serial method with thicknesses of $5 \mu \mathrm{m}$. The sections were subjected to Hematoxylin-Eosin (HE) staining for morphologicalhistomorphometric analysis (Ozaki et al., 2014).

Histological Analysis: For histomorphometric analysis, images of the slides stained with HE were obtained using the Nikon ${ }^{\circledR}$ eclipse $50 \mathrm{i}$ optical microscope attached to an Infinity 1 camera.

From the images, the area of cardiomyocytes was measured using the NIS-Elements software. For this, images were used with a 40x magnification, and 50 cardiomyocytes of each animal were measured (Junqueira et al., 2016).

Data analysis: After obtaining the data, the Shapiro-Wilk normality test was performed and the comparison between groups was carried out through the analysis of variances (ANOVA One-Way), followed by the Tukey post-test, for variables that demonstrated normality and the Kruskal-Wallis, followed by Dunn's post-test for variables that did not have normal distribution on the Gaussian curve. This procedure was performed for all variables obtained at the end of the experiment. All procedures adopted a significance value of 5 $\%(\mathrm{p}<0.05)$. The calculations were performed with the statistical package (SPSS 22.0 for Windows®).

\section{RESULTS}

The present study was composed of 39 male Wistar rats of 150 days of age. These animals were divided into four groups: Control (C), Fasting Control (FC), Training (T), and Fasting Training (FT).

In terms of body mass, the FT group presented an abrupt drop in this variable throughout the experiment, from the first to the fourth weighing, thus causing a statistically significant decrease in weight $(\mathrm{g})$ in relation to groups $\mathrm{C}$ $(\mathrm{p}=0.0001), \mathrm{FC}(\mathrm{p}=0.007)$, and $\mathrm{T}(\mathrm{p}=0.001)$.

The same occurred inversely with group $\mathrm{C}$, which showed an increase from the third assessment, but with no statistically significant result. The FC and T groups maintained weight values with little change. After statistical analysis, the final means of body mass of all groups throughout the intervention were as follows: C (439.07 \pm 3.58$)$; FC (433.76 $\pm 4.49) ; \mathrm{T}(437.64 \pm 3.70)$; FT $(412.03 \pm 4.10)$.

The differences between the means of the groups during the evaluations can be better identified in Figure 2 .

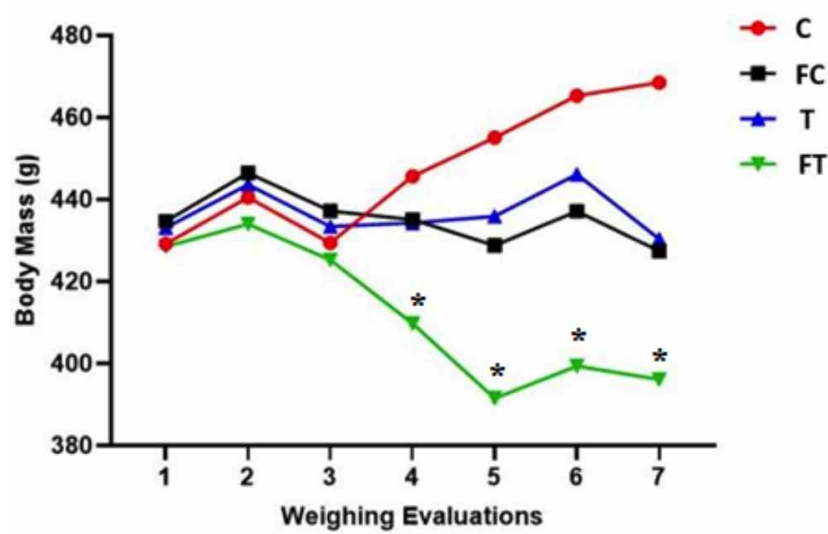

Fig. 2. Body mass of groups during the evaluations. $\mathrm{C}=$ Control group $; \mathrm{FC}=$ Fasting control group; $\mathrm{T}=$ Training group $; \mathrm{FT}=$ Fasting training group. Significant difference between FT and C, FC, and $\mathrm{T}$ (*). Statistically significant difference in the one-way ANOVA test with Tukey's post-test $(\mathrm{p}<0.05)$.

In relation to feed consumption (g), at the end of the experiment, the groups demonstrated the following respective means: $(\mathrm{C}=27.12 \pm 0.49) ;(\mathrm{FC}=35.41 \pm 1.48) ;(\mathrm{T}=26.20$ $\pm 1.45)$; $(\mathrm{FT}=22.31 \pm 0.62)$. After the statistical analysis of feed consumption, significant differences were noted between group $\mathrm{C}$ and groups $\mathrm{FC}(\mathrm{p}=0.001)$ and $\mathrm{FT}(\mathrm{p}=0.001) ; \mathrm{FC}$ and $\mathrm{T}(\mathrm{p}=0.001)$; and $\mathrm{T}$ and $\mathrm{C}(\mathrm{p}=0.001)$ (Fig. 3). 


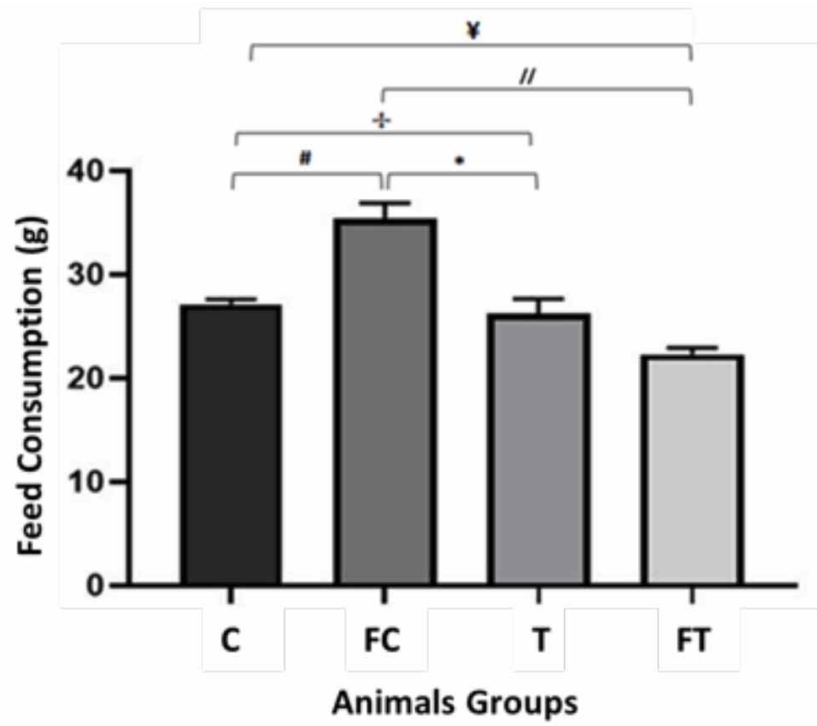

Fig. 3. Comparison of Feed Consumption between groups after the intervention. $\mathrm{C}=\mathrm{Control}$ group; $\mathrm{FC}=$ fasting control group; $\mathrm{T}$ $=$ Training group FT $=$ Fasting training group. Statistically significant difference in the one-way ANOVA test with Tukey's post-test $(\mathrm{p}<0.05)$. Description: $(*)=\mathrm{p}<0.05 \mathrm{C}$ vs FC; $(/ /)=\mathrm{p}<0.05$ CJ vs TJ; $(\dagger)=\mathrm{p}<0.05 \mathrm{C}$ vs FT; $(\dagger)=\mathrm{p}<0.05 \mathrm{FC}$ vs $\mathrm{T} ;(\S)=\mathrm{p}<0.05$ T vs FC; $(/ /)=\mathrm{p}<0.05 \mathrm{~T}$ vs FT.
After conducting the statistical analysis, no significant alterations were found related to the structural parameters evaluated by means of the echocardiographic study (Table I).

Mitral Valve Area (MVA $\left[\mathrm{cm}^{2}\right]$ ); Left ventricular internal diameter in systole (LVIDs [mm]); Left Ventricular Mass in diastole (LVMd Mass [g]); Left ventricular mass in systole (LVMs [g]); Left Ventricular Mass in diastole according to the American Society Echocardiogram formula (LVMd [ASE] [g]); Left Ventricular Mass in diastole according to the American Society Echocardiogram formula (LVMs [ASE] [g]); Left ventricular posterior wall in diastole (LVPWd [mm]); Left ventricular posterior wall in systole (LVPS [mm]); Relation between left atrium and aorta artery (LA/Ao); Interventricular septum in diastole (IVSd $[\mathrm{mm}]$ ); Interventricular septum in systole (IVSs [mm]); Diameter of the Aorta Artery (D Ao [mm]); Diameter of the Left Atrium (D LA [mm]). Significance: *p<0.05.

Regarding the functional parameters, no significant results were identified in either group (Table II).

Heart rate in beats per minute (HR [bpm]); Relationship between $\mathrm{E}$ wave and $\mathrm{A}$ wave of the mitral valve (E/A VM);

Table I. Results, with mean, standard error, and significance $(\mathrm{p}<0.05)$, of the structural parameters analyzed in the echocardiographic study.

\begin{tabular}{llllll}
\hline Structural P. & C & FC & T & FT & Sig. \\
\hline MVA $\left(\mathrm{cm}^{2}\right)$ & $8.60 \pm 1.70$ & $10.05 \pm 0.95$ & $8.63 \pm 4.56$ & $4.75 \pm 4.75$ & $p=0.36$ \\
D. Ao $(\mathrm{mm})$ & $2.92 \pm 0.32$ & $2.56 \pm 0.25$ & $2.31 \pm 1.15$ & $2.77 \pm 0.23$ & $p=0.83$ \\
D. LA (mm) & $3.20 \pm 0.35$ & $3.03 \pm 0.38$ & $2.61 \pm 1.30$ & $3.57 \pm 0.15$ & $p=0.74$ \\
AE/Ao & $1.07 \pm 0.15$ & $1.18 \pm 0.03$ & $0.75 \pm 0.37$ & $1.30 \pm 0.16$ & $p=0.58$ \\
IVSd (mm) & $1.60 \pm 0.19$ & $2.15 \pm 0.24$ & $2.03 \pm 0.21$ & $1.75 \pm 0.21$ & $p=0.31$ \\
LVPWd (mm) & $1.89 \pm 0.06$ & $1.90 \pm 0.58$ & $2.39 \pm 0.44$ & $1.46 \pm 0.09$ & $p=0.43$ \\
IVSs (mm) & $2.16 \pm 0.29$ & $2.55 \pm 0.86$ & $3.10 \pm 0.36$ & $2.52 \pm 0.12$ & $p=0.34$ \\
LVIDs (mm) & $4.89 \pm 0.16$ & $2.91 \pm 0.42$ & $3.60 \pm 0.56$ & $4.14 \pm 1.23$ & $p=0.51$ \\
LVPWs (mm) & $2.79 \pm 0.08$ & $2.52 \pm 0.47$ & $3.16 \pm 0.49$ & $2.70 \pm 0.55$ & $p=0.62$ \\
LVMd (g) & $12.61 \pm 0.08$ & $12.62 \pm 0.44$ & $12.27 \pm 0.30$ & $12.77 \pm 0.25$ & $p=0.66$ \\
LVMs (g) & $12.72 \pm 0.10$ & $13.01 \pm 0.34$ & $12.63 \pm 0.16$ & $12.82 \pm 0.15$ & $p=0.73$ \\
LVMd (ASE) (g) & $1.39 \pm 0.07$ & $1.37 \pm 0.35$ & $1.66 \pm 0.23$ & $1.27 \pm 0.20$ & $p=0.67$ \\
LVMs (ASE) (g) & $1.30 \pm 0.07$ & $1.06 \pm 0.27$ & $1.37 \pm 0.13$ & $1.22 \pm 0.12$ & $p=0.72$ \\
\hline
\end{tabular}

Table. II. Results, with mean, standard error, and significance, of the functional parameters analyzed in the echocardiographic study.

\begin{tabular}{llllll}
\hline Functional P. & C & FC & T & FT & Sig. \\
\hline Time $(\mathrm{ms})$ & $285.33 \pm 26.20$ & $371.50 \pm 64.50$ & $224.39 \pm 116.1$ & $325.50 \pm 25.50$ & $p=0.66$ \\
HR $(\mathrm{bpm})$ & $214.33 \pm 21.85$ & $167.00 \pm 29.00$ & $215.33 \pm 36.09$ & $185.50 \pm 14.50$ & $p=0.72$ \\
MV dp/dt $(\mathrm{mmHg} / \mathrm{s})$ & $36.00 \pm 12.66$ & $28.05 \pm 1.65$ & $36.90 \pm 25.40$ & $16.20 \pm 16.20$ & $p=0.61$ \\
E/A MV & $1.95 \pm 0.17$ & $1.95 \pm 0.38$ & $1.67 \pm 0.93$ & $1.20 \pm 0.20$ & $p=0.45$ \\
EF (teich) (\%) & $71.33 \pm 0.33$ & $89.00 \pm 1.00$ & $86.66 \pm 3.48$ & $79.00 \pm 11.00$ & $p=0.46$ \\
IVCT (ms) & $24.00 \pm 2.08$ & $24.00 \pm 1.00$ & $17.66 \pm 8.87$ & $27.50 \pm 4.50$ & $p=0.83$ \\
IVRT (ms) & $35.33 \pm 2.88$ & $33.33 \pm 4.27$ & $22.00 \pm 1.30$ & $24.66 \pm 21.36$ & $p=0.78$ \\
PHT MV (ms) & $27.33 \pm 4.70$ & $22.00 \pm 2.00$ & $11.66 \pm 6.17$ & $11.50 \pm 11.50$ & $p=0.12$ \\
V.A MV (cm/s) & $45.33 \pm 7.62$ & $39.00 \pm 7.00$ & $24.66 \pm 12.54$ & $41.00 \pm 15.00$ & $p=0.54$ \\
V.E MV (cm/s) & $87.66 \pm 12.97$ & $73.50 \pm 1.22$ & $59.66 \pm 31.31$ & $52.50 \pm 26.50$ & $p=0.39$ \\
\hline
\end{tabular}


Ejection Fraction (EF [teich] [\%]); Isovolumetric Contraction Time (IVCT [ms]); Isovolumetric Relaxation Time (IVRT [ms]); Mitral Valve Half Period Pressure (PHT VM [ms]); Ejection time (Time [ms]); Peak A Wave Velocity of mitral valve flow (V. A $\mathrm{VM}[\mathrm{cm} / \mathrm{s}]) ;$ (atrial contraction) Peak E Wave Velocity of mitral valve flow (rapid ventricular filling indicator) (V.E VM [cm/s]); and Rate of change of pressure over time in the mitral valve (LV function indicator) (MV dp/dt [mmHg/s]). Significance: ${ }^{*} \mathrm{p}<0.05$.

When the areas of the cardiomyocytes of the different groups were observed and compared, the following medians and interquartile ranges were obtained: C (317.92 - 188.24); FC (296.45 - 169.19); T (253.47 - 142.35), and FT (280.56 149.50). There was a statistically significant decrease in group $\mathrm{T}$ in relation to groups FT ( $\mathrm{p}=0.006) ; \mathrm{FC}(\mathrm{p}=0.0001)$; and $\mathrm{C}$ $(\mathrm{p}=0.0001)$. In addition, there was also a significant decrease in the area of cardiomyocytes in the FT group compared to the $\mathrm{C}$ group ( $\mathrm{p}=0.001$ ); and the $\mathrm{FC}$ group in relation to the $\mathrm{C}$ group $(\mathrm{p}=0.04)$. The alterations can be seen in Figure 4 .

From the analysis of the cardiomyocytes, different morphologies were found between the sample groups (Fig. 5). Thus, it can be observed that there was a decrease in the cardiomyocytes of the training group in relation to the cells of the other groups (Fig. 5.C).

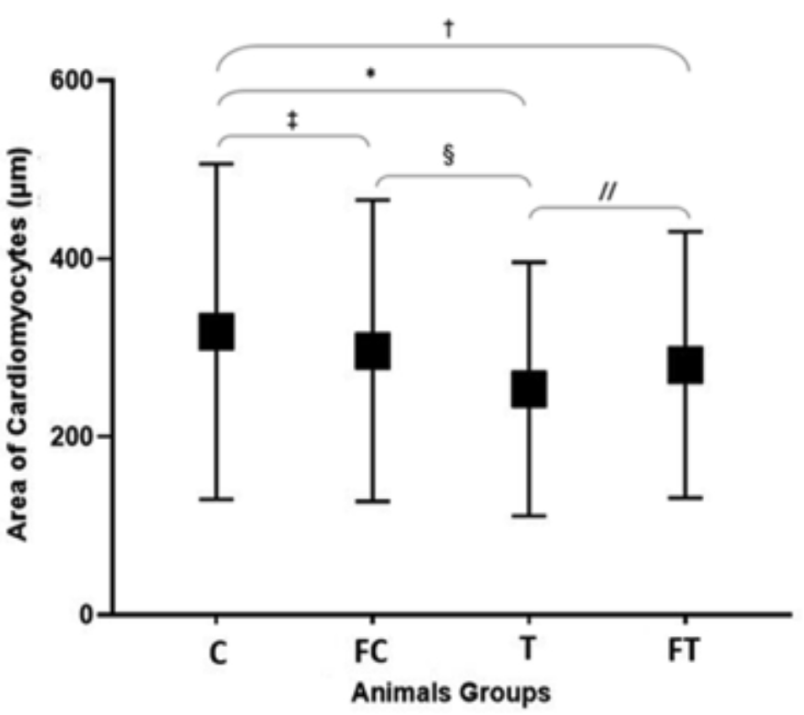

Fig. 4. Comparison of the Cardiomyocyte Area $(\mu \mathrm{m})$ between groups, after intervention. $\mathrm{C}=\mathrm{Control}$ group; $\mathrm{FC}=$ fasting control group; $\mathrm{T}=$ Training group; $\mathrm{FT}=$ Fasting training group. Statistically significant difference from the Kruskal-Wallis test with Dunn's post-test $(\mathrm{p}<0.05)$. Description: $(*)=\mathrm{p}<0.05 \mathrm{~T}$ vs $\mathrm{C} ;(\dagger)=\mathrm{p}<0.05$ FT vs $\mathrm{C} ;(\ddagger)=\mathrm{p}<0.05 \mathrm{FC}$ vs $\mathrm{C} ;(\S)=\mathrm{p}<0.05 \mathrm{~T}$ vs FC; $(/ /)=\mathrm{p}<0.05 \mathrm{~T}$ vs FT.
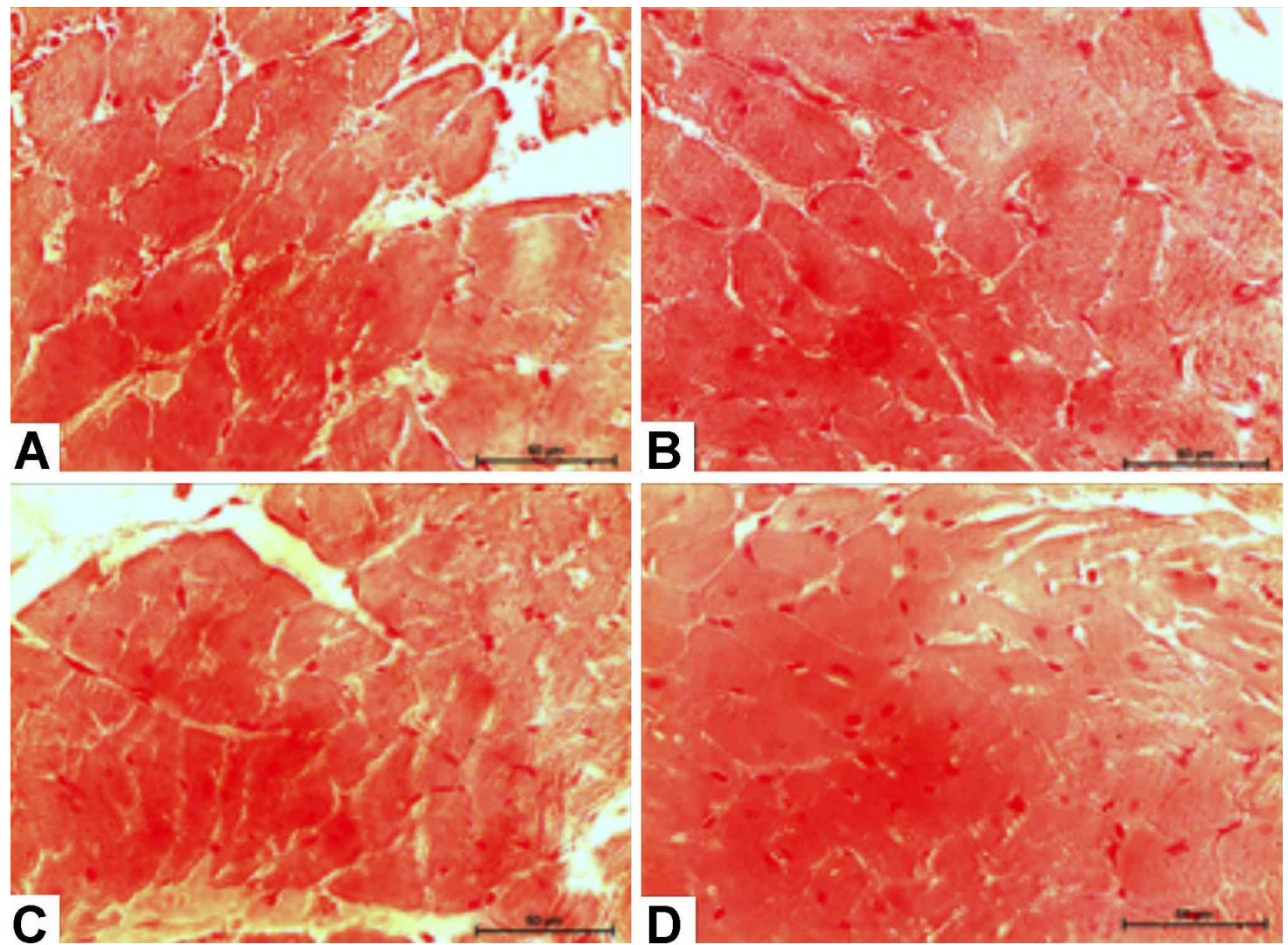

Fig. 5. Histology of cardiomyocytes from different sample groups. Description: (A) Control group. (B) Fasting control group. (C) Training group. (D) Fasting training group. 

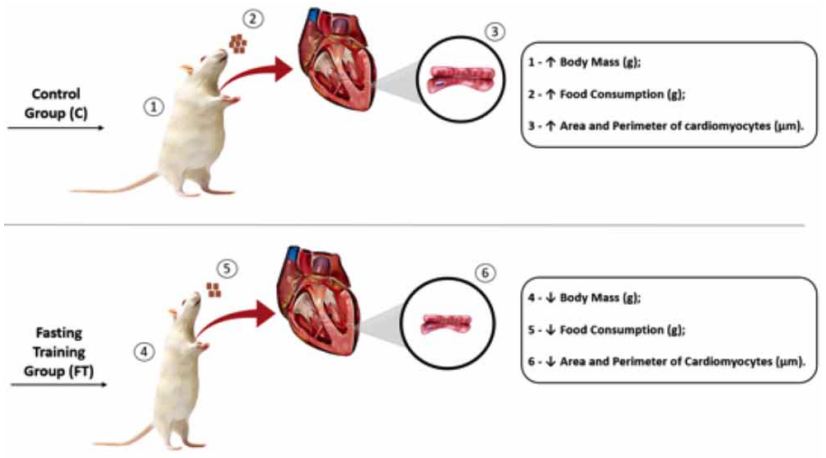

Fig. 6. Summary of results. Source: The author, 2021.

\section{DISCUSSION}

Concurrent training combined with intermittent fasting, applied in 12 sessions for 4 weeks, promoted cardiac atrophy without altering functional and structural aspects of cardiac remodeling.

According to the literature, it is known that both physical training and intermittent fasting are responsible for reducing levels of body fat, including representing viable options in the treatment of diseases such as obesity (Welton et al.). However, little is known about the results of prescribing these two methods in relation to the heart.

Regarding the structural parameters analyzed using the echocardiogram, no statistically significant alterations were observed. A study involving different training models showed that training with continuous load promoted an increase in heart weight in relation to the control group and the group that performed the training with progressive loads. On the other hand, high-intensity interval training, over a 6-week period, did not appear to alter heart weight and echocardiographic variables (Songstad et al., 2015).

With respect to aerobic training, in isolation, this proves to be more efficient when compared to resistance training and combined training, with regard to the left ventricle internal diameter. Thus, there is a hypothesis that the high load imposed by concurrent training may not be a very adaptive factor for this variable (de Souza et al., 2014).

Alterations in structural parameters such as left and right systolic ventricular diameter (LVIDs and LVIDd) and left ventricular mass (LVM) demonstrate a significant increase after the induction of myocardial infarction and resistance and aerobic training. Gomes et al. (2020) conducted a study with 4 groups of animals; a control group, a control induced to simulate myocardial infarction, and two groups that, respectively, performed aerobic and resistance training, 3 months after induced myocardial infarction. After 12 weeks of training, significant increases in the aforementioned structural parameters were identified in the training and simulation groups, in relation to the control group, thereby leading to the hypothesis that both exercise and myocardial infarction can cause alterations in cardiac structural parameters.

In the current study, when the functional parameters were evaluated, no significant results were found between the groups, thus differing from the study of Nunes et al. (2015), in which significant differences were observed between animals that performed continuous aerobic training and those that performed interval aerobic training, both with acute myocardial infarction, in relation to the control group. This fact can be justified either by the difference in intervention time, by the difference in the sample number, or by the difference in training models, thus it is assumed that the competition between anaerobic and aerobic metabolism can influence the lack of alteration in these parameters.

No significant alterations were identified in relation to heart rate in the present study, similar to the study of Nunes et al., which despite demonstrating alterations in most of the functional parameters, showed no difference in heart rate after an eight-week training period, thus agreeing with the study of Gomes et al., in which neither resistance climbing training nor treadmill aerobic training caused alterations in heart rate.

In parallel to the present study, results of functional parameters such as isovolumetric relaxation time (IVRT) and the relationship between mitral valve $\mathrm{E}$ and $\mathrm{A}$ wave (E/A MV) were not altered after performing aerobic and resistance training modalities, thus evidencing that physical exercise does not attenuate the values of the functional and structural parameters of the heart (Gomes et al.).

After performing the histological analysis, a decrease in the area of the cardiomyocytes was observed in the groups that trained and in the group that performed the fasting (FC, T, and FT), in relation to the same variable of cardiomyocytes in the control group. The fact that the groups that performed the training presented a decrease in the area of the cardiomyocytes can be justified by the intensity of the exercise, since the resistance training can cause injury to the cardiomyocytes, demonstrated by the increase in the concentration of creatine kinase musclebrain fraction (CK-MB), causing a decrease in the area of cardiomyocytes (Junqueira et al.). In addition, long-term aerobic training also causes an increase in CK-MB 
concentrations, resulting in damage to the sarcomeres of slow muscle fibers (Carmona et al., 2019).

In parallel, very intense endurance exercises attenuate the function of cardiomyocytes and impair mitochondrial adaptation due to the oxidative stress generated in these cells. Thus, to adapt to exercise, cardiomyocytes undergo apoptosis, so that new cells are generated with the intention of providing adaptation to the intensity of the exercise (Vujic et al., 2018). In addition, in cases of apoptotic deficiency, as well as not releasing anti-apoptotic factors that have therapeutic potential in regeneration cardiac arrest, including: growth factor derived from platelets (PDGF-BB) (Hsieh $e t$ al., 2006), thymosin protein b4 (Bock-Marquette et al., 2004), IL-11 (Obana et al., 2010), IL-33 (Seki et al., 2009), among others. High-intensity exercise can impair cardiac remodeling, resulting in cardiac fibrosis (Hsieh et al.; Ferraresso et al., 2012; Ljones et al., 2017; Yan et al., 2017).

Still dealing with cardiac remodeling, it is known that, for this physiological phenomenon to occur, there is a decrease in GLUT-4 and an increase in GLUT-1, a decrease in SERCA2a, an increase in galectin-3, replacement of the preferred energetic substrate of fatty acids for glucose, increased caveolin, increased expression of neuronal nitric oxide synthase, and increased angiotensin-converting enzyme (Swynghedauw, 2006; Zornoff et al., 2009; EXpert Group on Biomarkers, 2014). Thus, knowing that intermittent fasting is a method of food restriction, there is a chance that its performance will end up interfering with the release of these substrates/factors and consequently making cardiac remodeling difficult.

When comparing the area of cardiomyocytes between the $\mathrm{T}$ and FT groups, there was a smaller decrease in these variables in the fasting training group compared to the training group. This can be justified by the anti-apoptotic and anti-inflammatory protection that fasting offers cardiomyocytes (Ahmet et al., 2005). In this sense, these findings corroborate the study of Hickson (1980) which was the pioneer in observing the effect of "concurrency" and observed a decrease in the strength capacity of individuals who performed CT for more than eight weeks. In this case, there are indications that this training protocol may cause a decrease in the area of cardiomyocytes.

Given the above, the current study contributes to research in the area by verifying the effects of concurrent training combined with intermittent fasting on cardiomorphological and physiological parameters of Wistar rats. However, our study has limitations such as: the lack of biochemical analysis of the anaerobic threshold, the expression of proteins and genetic markers, and analysis of metabolites that could trigger structural alterations in the heart. Finally, research involving other mechanisms of cardiac remodeling with the concurrent training and intermittent fasting approach, may contribute to this research.

Finally, based on the results of the study, we conclude that the CT caused a decrease in the area of the cardiomyocytes. In addition, neither the CT nor the IF led to alterations in the functional and structural parameters of the heart.

\section{ACKNOWLEDGMENTS}

We thank the National Council for Scientific and Technological Development $(\mathrm{CNPq})$ for supporting the current research.

MARCELO, H. I.; ALEIXO, P. H.; DA SILVA, R. P.; PACAGNELLI, F. L.; DA SILVA, R. B. B. V.; CAMARGO FILHO, J. C. S.; ZANUTO, E. A. C. \& CASTOLDI, R. C. Efectos del entrenamiento concurrente y el ayuno intermitente sobre los parámetros estructurales, funcionales y morfológicos del corazón. Int. J. Morphol., 39(4):1190-1199, 2021.

RESUMEN: El ayuno intermitente y el entrenamiento concurrente se han realizado frecuentemente para disminuir la masa corporal. El objetivo fue analizar los efectos del entrenamiento concurrente (EC) y el ayuno intermitente (AI) sobre el remodelado cardíaco. En total, se utilizaron 39 ratas Wistar macho adultas, divididas en cuatro grupos: control $(\mathrm{C}[\mathrm{n}=12])$, control en ayunas (AC $[n=11])$, entrenamiento $(E[n=8])$ y ayuno, entrenamiento $[\mathrm{n}=8])$. El protocolo de EC estuvo compuesto de 12 sesiones, con 30 minutos de entrenamiento aeróbico (EA) en el medio líquido a una intensidad del $80 \%$ del umbral anaeróbico, seguido de entrenamiento de resistencia (ER) con 4 series de 10 saltos acuáticos correspondiente al $50 \%$ del peso corporal. El período de AI se estableció a las 12/12 horas, a partir de las 21:00 horas. finalizando a las 9 a.m. Se realizaron análisis ecocardiográficos antes y después de la intervención y, al finalizar el experimento, se recolectaron muestras del tejido cardíaco para realizar los análisis histológicos. El análisis de los datos se realizó mediante las pruebas de Shapiro-Wilk, Análisis de Varianza - ANOVA con pos test de Tukey y Kruskal-Wallis con postest de Dunn. Todos los procedimientos asumieron un error del $5 \%(\mathrm{p}<0,05)$. No se observaron alteraciones funcionales de los grupos (mín. $\mathrm{P}=0,12$ - máx. $\mathrm{P}=$ 0,83 ) y estructurales del corazón (mín. $\mathrm{P}=0,31$ - máx. $\mathrm{P}=0,83$ ). Se observó una disminución en el área de cardiomiocitos en los grupos $\mathrm{E}(\mathrm{p}=0,001)$ y EA $(\mathrm{p}=0,001)$. La EC y la AI no alteraron los parámetros funcionales y estructurales del corazón, pero sí provocaron una disminución del área de los cardiomiocitos.

PALABRAS ClAVE: Histología; Cardiología; Corazón; Ratas ejercicio. 


\section{REFERENCES}

Ahmet, I.; Wan, R. ; Mattson, M. P. ; Lakatta, E. G. \& Talan, M. Cardioprotection by intermittent fasting in rats. Circulation, 112(20):3115-21, 2005

Atluri, P. \& Woo, Y. J. Pro-angiogenic cytokines as cardiovascular therapeutics: assessing the potential. BioDrugs, 22(4):209-22, 2008.

Beltrami, A. P.; Barlucchi, L.; Torella, D.; Baker, M.; Limana, F.; Chimenti, S.; Kasahara, H.; Rota, M.; Musso, E.; Urbanek, K.; et al. Adult cardiac stem cells are multipotent and support myocardial regeneration. Cell, 114(6):763-76, 2003.

Biesek, S. \& Alves, L. Determinando as Necessidade Energéticas. 2nd ed. Barueri, Manole, 2010.

Bock-Marquette, I.; Saxena, A.; White, M. D.; Dimaio, J. M. \& Srivastava, D. Thymosin beta4 activates integrin-linked kinase and promotes cardiac cell migration, survival and cardiac repair. Nature, 432(7016):466-72, 2004.

Carmona, G.; Roca, E.; Guerrero, M.; Cussó, R.; Bàrcena, C.; Mateu, M. \& Cadefau, J. A. Fibre-type-specific and mitochondrial biomarkers of muscle damage after mountain races. Int. J. Sports Med., 40(4):25362, 2019.

Castoldi, R. C.; Camargo, R. C. T.; Magalhães, A .J. B.; Ozaki, G. A. T.; Kodama, F. Y.; Oikawa, S. M.; Papoti, M. \& Camargo Filho, J. C. S. Concurrent training effect on muscle fibers in wistar rats. Motriz Rev. Educ. Fis., 19(4):717-23, 2013.

Chimin, P.; Araújo, G. G.; Manchado-Gobatto, F. B. \& Gobatto, C. A. Critical load during continuous and discontinuous training in swimming Wistar rats. Motricidade, 5(4):45-58, 2009.

de Souza, M. R.; Pimenta, L.; Pithon-Curi, T. C.; Bucci, M.; Fontinele, R. G. \& de Souza, R. R. Effects of aerobic training, resistance training, or combined resistance-aerobic training on the left ventricular myocardium in a rat model. Microsc. Res. Tech., 77(9):727-34, 2014.

Dudley, G. A. \& Fleck, S. J. Strength and endurance training. Are they mutually exclusive? Sports Med., 4(2):79-85, 1987.

EXpert Group on Biomarkers. Biomarkers in cardiology--part 1--in heart failure and specific cardiomyopathies. Arq. Bras. Cardiol., 103(6):4519, 2014.

Ferraresso, R. L. P.; de Oliveira, R. B.; Macedo, D. V.; Nunes, L. A. S.; Brenzikofer, R.; Damas, D. \& Hohl, R. Interaction between overtraining and the interindividual variability may (not) trigger muscle oxidative stress and cardiomyocyte apoptosis in rats. Oxid. Med. Cell. Longev., 2012:935483, 2012.

Ferreira da Silva, M.; Pelúzio, M. C. G.; dos Santos Amorim, P. R.; Lavorato, V. N.; do Santos, N. P.; Bozi, L. H. M.; Penitente, A. R.; Falkoski, D. L.; Berfort, F. G. \& Natali, A. J. Swimming training attenuates contractile dysfunction in diabetic rat cardiomyocytes. Arq. Bras. Cardiol., 97(1):33-9, 2011.

Fontan, J. S. \& Amadio, M. B. O uso do carboidrato antes da atividade física como recurso ergogênico: revisão sistemática. Rev. Bras. Med. Esporte, 21(2):153-7, 2015.

Gimenes, C.; Gimenes, R.; Rosa, C. M.; Xavier, N. P.; Campos, D. H. S.; Fernandes, A. A. H.; Cezar, M. D. M.; Guirado, G. N.; Cicogna, A. C.; Takamoto, A. H. R.; et al. Low intensity physical exercise attenuates cardiac remodeling and myocardial oxidative stress and dysfunction in diabetic rats. J. Diabetes Res., 2015:457848, 2015.

Gomes, M. J.; Pagan, L. U.; Lima, A. R. R.; Reyes, D. R. A.; Martinez, P. F.; Damatto, F. C.; Pontes, T. H. D.; Rodrigues, E. A.; Souza, L. M.; Tosta, I. F.; et al. Effects of aerobic and resistance exercise on cardiac remodelling and skeletal muscle oxidative stress of infarcted rats. $J$. Cell. Mol. Med., 24(9):5352-62, 2020.

Henry, T. D.; Annex, B. H.; McKendall, G. R.; Azrin, M. A.; Lopez, J. J.; Giordano, F. J.; Shah, P. K.; Willerson, J. T.; Benza, R. L.; Berman, D. $\mathrm{S}$; et al. VIVA Investigators. The VIVA trial: Vascular endothelial growth factor in Ischemia for Vascular Angiogenesis. Circulation, 107(10):1359-65, 2003.
Hickson, R. C. Interference of strength development by simultaneously training for strength and endurance. Eur. J. Appl. Physiol. Occup. Physiol., 45(2-3):255-63, 1980 .

Hill, D. W. The critical power concept. A review. Sports Med., 16(4):23754, 1993.

Hsieh, P. C. H.; Davis, M. E.; Gannon, J.; MacGillivray, C. \& Lee, R. T. Controlled delivery of PDGF-BB for myocardial protection using injectable self-assembling peptide nanofibers. J. Clin. Invest., 116(1):237-48, 2006.

Junqueira, A.; Cicogna, A. C.; Engel, L. E.; Aldá, M. A.; de Tomasi, L. C.; Giuffrida, R.; Giometti, I. C.; Freire, A. P. C. F.; Aguiar, A. F. \& Pacagnelli, F. L. Effects of Growth Hormone on Cardiac Remodeling During Resistance Training in Rats. Arq. Bras. Cardiol., 106(1):18-25, 2016

Kleiner, M. S. Nutrição para o Treinamento de Força. 3rd ed. Barueri, Manole, 2009. pp.72.

Lang, R. M.; Bierig, M.; Devereux, R. B.; Flachskampf, F. A.; Foster, E.; Pellikka, P. A.; Picard, M. H.; Roman, M. J.; Seward, J.; Shanewise, J. S.; et al. Recommendations for chamber quantification: a report from the American Society of Echocardiography's Guidelines and Standards Committee and the Chamber Quantification Writing Group, developed in conjunction with the European Association of Echocardiography, a branch of the European Society of Cardiology. J. Am. Soc. Echocardiogr., 18(12):1440-63, 2005.

Ljones, K.; Ness, H. O.; Solvang-Garten, K.; Gaustad, S. E. \& Høydal, M. A. Acute exhaustive aerobic exercise training impair cardiomyocyte function and calcium handling in Sprague-Dawley rats. PLoS One, 12(3):e0173449, 2017.

Manchado, F. B.; Gobatto, C. A.; Contarteze, R. V. L.; Papoti, M. \& Mello, M. A. R. Máxima fase estável de lactato é ergômetro-dependente em modelo experimental utilizando ratos. Ver. Bras. Med. Esporte, 12(5):259-62, 2006

Marangon, L.; Gobato, C. A.; de Mello, M. A. R. \& Kokobun, E. Utilization of an hyperbolic model for the determination of the critical load in swimming rats. Med. Sci. Sports Exerc., 34(5):S149, 2002.

Marquezi, M. L. \& Dos Santos Costa, A. Implicações do jejum e restrição de carboidratos sobre a oxidação de substratos. Rev. Mackenzie Educ. Fis. Esporte, 7(1):119-29, 2008.

Mayfield, A. E.; Tilokee, E. L. \& Davis, D. R. Resident cardiac stem cells and their role in stem cell therapies for myocardial repair. Can. J. Cardiol., 30(11):1288-98, 2014.

Mccardle, W.; Katch, F. \& Katch, V. L. Nutrição para o Desporto e o Exercício. 8th ed. Rio de Janeiro, Guanabara, 2017.

Minicucci, M. F.; Azevedo, P. S.; Ardisson, L. P.; Okoshi, K.; Matsubara, B. B.; Matsubara, L. S.; Paiva, S. A. R. \& Zornoff, L. A. M. Relevância do padrão de remodelamento ventricular no modelo de infarto do miocárdio em ratos. Arq. Bras. Cardiol., 95(5):635-9, 2010.

Ministério da Saúde. Mês de Ano Universidade Federal de Minas Gerais. Desmistificando Dúvidas sobre Alimentação e Nutrição. Brasília, Ministério da Saúde, Brasil, 2016. pp.137-8.

Negrão, E. C. Cardiologia do Exercício: do Atleta ao Cardiopata. 3rd ed. Barueri, Manole, 2010. pp.35.

Noh, J.; Wende, A. R.; Olsen, C. D.; Kim, B.; Bevins, J.; Zhu, Y.; Zhang, Q. J.; Riehle, C. \& Abel, E. D. Phosphoinositide dependent protein kinase 1 is required for exercise-induced cardiac hypertrophy but not the associated mitochondrial adaptations. J. Mol. Cardiol., 89 Part $B: 297-305,2015$.

Nunes, R. B.; Alves, J. P.; Kessler, L. P.; Dornelles, A. Z.; Stefani, G. P. \& Lago, P. D. Interval and continuous exercise enhances aerobic capacity and hemodynamic function in CHF rats. Braz. J. Phys. Ther, 19(4):257$63,2015$.

Obana, M.; Maeda, M.; Takeda, K.; Hayama, A.; Mohri, T.; Yamashita, T.; Nakaoka, Y.; Komuro, I.; Takeda, K.; Matsumiya, G.; et al. Therapeutic activation of signal transducer and activator of transcription 3 by interleukin-11 ameliorates cardiac fibrosis after myocardial infarction. Circulation, 121(5):684-91, 2010. 
Ozaki, G. A. T.; Koike, T. E.; Castoldi, R. C.; Garçon, A. A. B.; Kodama, F. Y.; Watanabe, A. Y.; Job, A. E.; Louzada, M. J. Q.; Camargo, R. C. T. \& Camargo Filho, J. C. S. Efeitos da remobilização por meio de exercício físico sobre a densidade óssea de ratos adultos e idosos. Motricidade, 10(3):71-8, 2014

Ozaki, G.; Camargo, R. C. T.; Koike, T. E.; Garcia, T. A.; Castoldi, R. C. \& Camargo Filho, J. C. S. Fractal analysis of skeletal muscle tissue of rats subjected to stretch injury. Int. J. Morphol., 33(3):908-13, 2015.

Pearson, M. J.; Mungovan, S. F. \& Smart, N. A. Effect of exercise on diastolic function in heart failure patients: a systematic review and metaanalysis. Heart Fail. Rev., 22(2):229-42, 2017.

Seki, K.; Sanada, S.; Kudinova, A. Y.; Steinhauser, M. L.; Handa, V.; Gannon, J. \& Lee, R. T. Interleukin-33 prevents apoptosis and improves survival after experimental myocardial infarction through ST2 signaling. Circ. Heart Fail., 2(6):684-91, 2009.

Songstad, N. T.; Kaspersen, K. H. F.; Hafstad, A. D.; Basnet, P.; Ytrehus, K. \& Acharya, G. Effects of high intensity interval training on pregnant rats, and the placenta, heart and liver of their fetuses. PLoS One, 10(11):e0143095, 2015.

Swynghedauw, B. Phenotypic plasticity of adult myocardium: molecular mechanisms. J. Exp. Biol., 209(Pt. 12):2320-7, 2006.

Taimeh, Z.; Loughran, J.; Birks, E. J. \& Bolli, R. Vascular endothelial growth factor in heart failure. Nat. Ver. Cardiol., 10(9):519-30, 2013.

Testa, U.; Pannitteri, G. \& Condorelli, G. L. Vascular endothelial growth factors in cardiovascular medicine. J. Cardiovasc. Med. (Hagerstown), 9(12):1190-221, 2008.

Vujic, A.; Lerchenmüller, C.; Wu, T. D.; Guillermier, C.; Rabolli, C. P.; Gonzalez, E.; Senyo, S. E.: Liu, X.; Guerquin-Kern, J. L.; Steinhauser, M. L.; et al. Exercise induces new cardiomyocyte generation in the adult mammalian heart. Nat. Commun., 9(1):1659, 2018.

Welton, S.; Minty, R.; O'Driscoll, T.; Willms, H.; Poirier, D.; Madden, S. \& Kelly, L. Intermittent fasting and weight loss: Systematic review. Can. Fam. Physician, 66(2):117-25, 2020.

Yan, Z.; Kronemberger, A.; Blomme, J.; Call, J. A.; Caster, H. M.; Pereira, R. O.; Zhao, H.; de Melo, V. U.; Laker, R. C.; Zhang, M.; et al. Exercise leads to unfavourable cardiac remodelling and enhanced metabolic homeostasis in obese mice with cardiac and skeletal muscle autophagy deficiency. Sci. Rep., 7(1):7894, 2017.

Zornoff, L. A. M.; Paiva, S. A. R.; Duarte, D. R. \& Spadaro, J. Ventricular remodeling after myocardial infarction: concepts and clinical implications. Arq. Bras. Cardiol., 92(2):150-64, 2009.

\author{
Corresponding author: \\ Henrique Izaias Marcelo \\ Universidade Estadual Paulista \\ Educational Center - Histology and Histochemistry \\ Laboratory \\ Júlio de Mesquita Filho \\ Roberto Simonsen St, 305 \\ 19060900 - Presidente Prudente, SP \\ BRAZIL
}

E-mail: henrique.izaias99@gmail.com

Received: 18-04-2021

Accepted: 27-05-2021 